\title{
A post-Jungian perspective on the psychological development of Afrikaner cultural identity
}

\author{
Authors: \\ Martina Kotzé ${ }^{1}$ \\ Loura Griessel ${ }^{2}$ \\ Affiliations: \\ ${ }^{1}$ Business School, University \\ of the Free State, \\ Bloemfontein, South Africa \\ ${ }^{2}$ Department of Industrial \\ Psychology, University of the \\ Free State, Bloemfontein, \\ South Africa \\ Correspondence to: \\ Martina Kotzé \\ Email: \\ kotzem@ufs.ac.za \\ Postal address: \\ PO Box 339, Bloemfontein \\ 9300 , South Africa \\ Dates: \\ Received: 19 Aug. 2010 \\ Accepted: 02 Apr. 2012 \\ Published: 13 Dec. 2012 \\ How to cite this article: \\ Kotzé, M. \& Griessel, L., 2012, \\ 'A Post-Jungian perspective \\ on the psychological \\ development of Afrikaner \\ cultural identity', Koers \\ - Bulletin for Christian \\ Scholarship 77(2), Art. \#54, \\ 10 pages. http://dx.doi. \\ org/10.4102/koers.v77i2.54
}

C) 2012. The Authors

Licensee: AOSIS

OpenJournals. This work

is licensed under the

Creative Commons

Attribution License.
In order to enhance an understanding of different cultures and groups, post-Jungians are currently applying C.G. Jung's theory of personal ego and complexes to the cultural level of the psyche of groups. In the post-Jungian view, much of what tears groups apart can be understood as the manifestation of autonomous processes in the collective and individual psyche that organise themselves around the cultural identity and cultural complexes of groups. A post-Jungian model of the development of the Self, based on Jung's early identification of the archetypal patterns of Masculine and Feminine, was used to explore and discuss the development and formation of the Afrikaner cultural identity and its concomitant complexes within South Africa as they were shaped by important historical events. The interplay between the Masculine and Feminine principles led to the argument that, within the premises of the model, Afrikaner identity was forged by traumatic events in the static Feminine, which lead to a gross overemphasis of the Masculine in its dynamic and, more especially, in its static forms, reverberating in the notorious nationalist strategy of Apartheid. It was further argued that that the change and transformation of the Afrikaner cultural identity under the auspices of the dynamic Feminine was inevitable, leaving the Afrikaner in a situation in which the reconstruction of their cultural identity or identities is still emerging. It was concluded that, since all human cultures are seen as having their roots in and being centred around a religious viewpoint, as was evident in the Great Father-God, Calvinistic, patriarchal ethic of the Afrikanerdom, the individuation of the Afrikaner and the evolution of the Afrikaner cultural identity will most probably include a renewal of some of its religious viewpoints.

'n Post-Jungiaanse perspektief op die psigologiese ontwikkeling van die kulturele identiteit van die Afrikaner. C.G. Jung se teorie oor persoonlike ego en komplekse word tans aangewend op die kulturele vlak van die psige van groepe, ten einde 'n beter begrip van verskillende kulture te bewerkstellig. Volgens die post-Jungiaanse perspektief kan die oorsake van dit wat groepe uitmekaar dryf dikwels toegeskryf word aan die manifestasie van outonome prosesse in die kollektiewe en individuele psige, wat hulself organiseer rondom kulturele identiteit en kulturele komplekse van groepe. 'n Post-Jungiaanse model van die ontwikkeling van die Self, gebaseer op Jung se vroeë identifisering van die argetipiese patrone van Manlik en Vroulik, is gebruik om die ontwikkeling en totstandkoming van die Afrikaner se kulturele identiteit en gepaardgaande komplekse, soos gevorm deur belangrike historiese gebeure, te ondersoek. Gebaseer op die interaksie tussen die Manlike en die Vroulike beginsels, is, binne die aanname van die model, geargumenteer dat die Afrikaner se identiteit sy oorsprong het in traumatiese gebeure wat in die statiese Vroulike plaasgevind het. Dit het tot die oorbeklemtoning van die Manlike in sy dinamiese en veral statiese vorme gelei, wat uiteindelik beslag gevind het in die berugte nasionale strategie van Apartheid. Daar is verder aangevoer dat die verandering en transformasie ten opsigte van die kulturele identiteit van die Afrikaner, onder die invloed van die dinamiese Vroulike, onvermydelik was. Dit het die Afrikaner in 'n situasie gelaat waar die rekonstruksie van hulle kulturele identiteit steeds in ' $\mathrm{n}$ vormingsproses was. Die gevolgtrekking is gemaak dat, aangesien alle kulture gewortel is in, en gesentreer word rondom bepaalde godsdienstige ootuiginge, soos dit duidelik was in die Vader-God, Calvinistiese, patriargale etiek van die Afrikanerdom, die individuasie van die Afrikaner, asook die evolusie van die Afrikaner kulturele identiteit, heelwaarskynlik die hernuwing van sommige van die godsdienstige oortuiginge van die Afrikaner sal insluit.

\section{Introduction}

Understanding both the uniqueness and commonality of cultures from around the world has become essential for the well-being of the global community itself. In this quest to enhance an understanding of different cultures and groups, post-Jungian researchers have further developed C.G. Jung's original theories and ideas and applied it at a group level. This body of research offers 
a new perspective on the psychological nature of groups and cultures (Singer \& Kimbles 2004; Hill 1992).

One of Jungian psychology's main thrusts is its perspective that the human psyche consists of conscious and unconscious parts. The unconscious part can be personal as well as collective. The personal ego, regarded as the centre of the psyche's consciousness, refers to a distinct 'I-ness' and is seen as the subject of all personal acts of consciousness (Stein 2010:15). The collective unconscious contains and functions as a deposit of all human experience and this is where the archetypes (typical structuring patterns of psychological functioning) reside. In its endeavour to understand human functioning, Jungian psychology embraces the universe in all it manifestations, including components such as history, art, myth, philosophy and spirituality (Jung 1977:5). Furthermore, in every human being all these structures are engaged as the drive towards purposive psychological development, referred to as the individuation process, which is driven by the archetype of the Self (unifying principle of the psyche). In Jungian psychology the Self is a more inclusive word for the inner image of God, the imago Dei, which resides in every person, whilst the life of Christ, as the Redeemer and the symbol of the Self, represents transformation and the various stages of the process of individuation (Jung 1969:347). One of the central components of Jung's theory is this continuous drive of the psyche towards the development of consciousness and the integration of these structures in order to create wholeness (Stein 2010:171-197).

During the process of interaction between the individual's personal ego and the environment, the affective memories of experiences, both bad and good, often tend to be repressed and to cluster around the relevant archetypical potentialities, thereby forming what Jung referred to as 'complexes'. These personal complexes emerge out of the level of the personal unconscious in their interaction with deeper levels of the psyche and early parental or familial relationships (Jung 1966). Complexes can hinder ego development and the ego's natural capacity to unfold toward the fullest possible realisation of the Self (wholeness) (Hill 1992:107).

Post-Jungians apply Jung's framework of ego development or individuation to the group level and refer to the national identity of a specific group as the cultural ego or cultural identity, thus referring to the centre of the group's consciousness (Singer \& Kimbles 2004:5). During the formation of the cultural ego cultural complexes can arise out of the cultural unconscious as they interact with both the archetypical and personal realm of the psyche and the broader outer world arena of schools, communities, media and all the other forms of cultural and group life (Singer \& Kimbles 2004:4). Cultural complexes are not the same as cultural identity (or cultural ego) although there are times when cultural complexes and cultural identity can seem intertwined. Cultural complexes are based on repetitive, historical group experiences which have taken root in the cultural unconscious of the group. At any time, these complexes can be activated, after which they take hold of the collective psyche of the group. They sometimes inhabit the cultural identity of a group and then operate like the group ego (Singer \& Kimbles 2004:5). In the post-Jungian view, much of what tears groups apart can be understood as the manifestation of autonomous processes in the collective and individual psyche that organise themselves around the cultural identity and cultural complexes of groups. According to the Jungian paradigm, complexes can be transformed when individuals become conscious of their existence and by integrating them as much as possible into the individual and group consciousness.

This article draws on post-Jungian work on the development of the ego and offers a new understanding of the development of the cultural ego of the Afrikaner volk and its concomitant complexes. For these purposes, Hill's (1992:23-52) model for the development of the Self, based on C.G. Jung's early identification of the archetypical patterns of Masculine and Feminine, will be used.

\section{Hill's model of the development of the Self}

The Masculine and the Feminine as archetypes and the part they play in ego development, consciousness and individuation are crucial components of Jung's work. Jung recognises that the Feminine aspects of the psyche, such as nurturance, interrelatedness, immersion in life and empathy, are are not inferior to the Masculine elements, such as autonomy, separateness, and aggressiveness. Post-Jungians have argued consistently that the Feminine and Masculine, as archetypical principles, presuppose styles of being human which apply to both men and women (Mattoon 1981:83-101; Samuels 1985:207-229; Whitmont 1983:109-122). Symbolically, the Feminine and Masculine are therefore understood as archetypical aspects of the human psyche and as psychic modalities that belong to both genders and to all cultures (Ulanov 1971:154-157).

Hill (1992) subsequently proposes a model of the development of the Self, with the fundamental premise that four basic patterns underlie all human activity, namely the static Feminine, the dynamic Masculine, the static Masculine, and the dynamic Feminine. A description of each of the principles and the pattern that flows from it follows.

\section{The static Feminine}

The archetypical image that expresses the essence of the static Feminine is the Great Mother in both her positive and negative aspects (The Good Mother and Terrible Devouring or Persecutory Mother) (Hill 1992:4-9; Neumann 1971:25-31; Whitmont 1980:109-122). Constancy, consistency, and balance in the organism of nature as a whole are her highest values. The static quality of the Feminine is the basis for the stable and enduring quality of the Feminine, which dominates in motherhood (Ulanov 1971:158) and in the recurring tasks, in the care of the family, of the house-husband or housewife (Hill 1992:7). The positive effect of these elemental aspects of 
the Feminine makes itself felt in such emotional responses as feeling secure, protected, fundamentally accepted and acceptable, with a reservoir of hope and possibility (Ulanov 1971:58). The static Feminine is symbolised most aptly by a circle, representing an undifferentiated whole (Hill 1992:5). When too dominant, the static Feminine represents its negative aspect, leading to smothering entanglement, inertia, feelings of paralysis, and of ensnaring and devouring routine, amongst other things.

\section{The dynamic Masculine}

Hill (1992:10) argues that the dynamic Masculine is in direct contrast to the static aspect of the Feminine principle. The dynamic Masculine focuses on the drive to conquer and master in the service of a differentiated individualism. The highest goal of the dynamic Masculine is the mastery and harnessing of nature in the service of life-giving technology. Its central values are progress, 'begetting new means, and becoming' (Hill 1992:12), and it is expressed in initiative and action directed towards a goal. In the Western world it is associated with the highest level of cognitive operations, such as 'objective analysis' and linear expression. The dynamic Masculine is symbolised most aptly by the arrow (Hill 1992:12). When in excess and dominant, the negative dynamic Masculine is wilful, inflated, determined and goaldirected at the expense of what is life-giving and natural, and despotism may be constellated in a disregard for nature and/or human life (Hill 1992:12).

\section{The static Masculine}

As archetypal principle or originating force the static Masculine, in its positive aspects, generates a pull toward order, standards, systems of meaning, rules and regulations, theories of truth and impersonal objectivity in discriminating and judging. Its primary value is Logos, and it is symbolised most aptly by a cross, representing opposites held in the differentiated tension of an ordered state (Hill 1992:13). At the human level, its fundamental expression is found in the tendencies toward social organisation in a hierarchical order. The static Masculine can also be seen in the archetypical image of the Great Father (Good Father and Terrible Father) or the King holding symbols of power (Hill 1992:13; Sullivan 1989:18-19). The negative aspect of the static Masculine emerges when it is excessive and unbridled. Order and organisation for their own sake lead to complacency, rigidity, dehumanising righteousness, inauthenticity and lifelessness - sapping spontaneity and creativity, and blocking the means of renewal (Hill 1992:16).

\section{The dynamic Feminine}

The dynamic aspect of the Feminine principle stands in opposition to the static aspect of the Masculine principle (Hill 1992:17). Whereas the static Masculine insists on reasoned Logos and order, the dynamic Feminine urges change and transformation. It encompasses the flow of experience, undirected movement towards the new, the non-rational, and the playful. It is spontaneous, open to the unexpected, yielding, and responsive to being acted upon. The dynamic Feminine brings the disorienting and transforming experience of awareness that breaks down existing and 'known' categories of consciousness through the introduction of new possibilities and unexpected elements into the imagination of outer experience. It involves a process of transformation, often in service of a new sense of wholeness and transformed awareness (Hill 1992:20). It is symbolised most aptly by a spiral (Hill 1992:20). When in excess, the effects of the negative dynamic Feminine are altered states of onsciousness which do not move beyond disintegration, but deeply into states of deepening chaos, emptiness, despair, and death. A lack of movement towards a new synthesis is then evident (Hill 1992:20; Ulanov 1971:160-162).

Following the critical interpretations of the principles of the Feminine and Masculine, Hill (1992:23-26) argues that the four patterns in which they take form assume two polarities of opposites or complementarities in the unfolding of the Self, namely the static Feminine or dynamic Masculine and the static Masculine or dynamic Feminine polarities. Energy flows in a compensatory movement through the model in an archetypically conditioned way. In a typical ego development cycle, containment is found in the static Feminine. The typical response to the static Feminine experience is the awakening of the dynamic Masculine and its movement towards separation-individuation and differentiation. The countervailing influence for the dynamic Masculine is the activation of the static Masculine. Under the auspices of the static Masculine archetypical influence, a period of integration is begun toward the goal of achieving a place in the existing order through the building of structures.

However, this integration can lead to one-sidedness of development, as many other potentialities in the Self still remain unconscious. The dynamic Feminine (as it compensates the static Masculine) awakens a crisis of meaning and authenticity. The static Masculine breaks down and, because of a longing for renewal, may lead to abandonment or alteration of structures. In the Jungian ideal, the dynamic Feminine leads to a watery initiation that dissolves old patterns, and creates new ones. The static Masculine orientation dies and is replaced by a consciousness that is more reflective of the Self. It begins to be manifested as a new wisdom about the nature and meaning of the experience of being human, and is called individuation (Hill 1992:30). This can lead to an experience of wholeness, a state of renewed union with one's wholeness (as it is engendered by a new static Feminine wisdom).

In Hill's view a complex forms whenever there is a fixation on a polarity. The ego is then caught in a bipolar complex where it tends to identify with one pole of the polarity and to project the other. Hill's (1992:148) model will subsequently be utilised as a framework in order to identify the psychological developmental patterns underlying historical events that shaped the development and formation of the Afrikaner cultural identity and complexes over the past few centuries. 


\section{The Masculine and Feminine in the development of White Afrikaner cultural identity}

\section{The static Feminine in Afrikaner cultural identity: Traumatic separation from 'Mother Europe'}

The first immigrants from Europe to South Africa landed at the Cape, the most southerly part of the country, in the middle of the 17th century. These Dutch and French immigrants slowly spread their wings, founding remote rural settlements ever further afield. In time they became known as Boere (farmers), and later as Afrikaners (Leach 1989:1). According to Faber (1990:57) many of these immigrants were followers of Calvinist Protestantism, whose members had found themselves in the position of a persecuted minority and had had to defend themselves by means of armed resistance against Catholic-inspired repression and even massacre, before, ultimately, having had to flee from Europe. From this perspective, the experience of the inadequate and insufficient safety and security provided by the static Feminine (Mother Europe), imaged as the 'Terrible Devouring/Persecutory Mother', was evident in the experiences of many of these immigrants.

Furthermore, when these immigrants found their independence in their new country cut short by the arrival of the British at the end of the 18th century (Leach 1989:1), their dread of being swallowed by the Feminine and the continuing threat of annihilation were reinforced. Seen as the new agents of the 'Terrible Devouring/Persecutory Mother', the British proceeded systematically to intensify the 'threat' through a policy of Anglicisation, the emancipation of the slaves and the equalisation of Mixed-race people with White people (seen as unacceptable and in conflict with the laws of God by the Calvinistic Boere) (Faber 1990:57).

Because of their history of persecution and their experience of forced and traumatic separation from Mother Europe, primary fears relating to survival and separation were constellated in the Afrikaners. Since complexes form around traumatic events, discrimination, feelings of oppression and inferiority at the hands of another offending group (Singer \& Kimbles 2004:7), it can be argued that the negative aspects of the static Feminine, imaged in the 'Terrible Devouring/ Persecutory Mother', were constellated as a complex in their collective psyche. The complex would imply that the Afrikaners may often feel that they are under threat of being devoured or persecuted. These archaic anxieties lead to a violent Masculine protest against, and assault upon, inadequate static Feminine experiences, and would become clearly evident in the subsequent formation of the Afrikaner's cultural identity. In order to escape British rule (and possibly the 'Devouring/Persecutory Mother'), the Boere started the Great Trek from the Cape to the North in 1838, across the vast, rugged and untamed interior of South Africa, pursuing a dream of White Afrikaner independence (Jacobs 2005:20; Landman 1994:3).

\section{The dynamic Masculine in Afrikaner cultural identity: Separation and differentiation through pilgrimages and wars}

According to Hill's model (1992), the static Feminine has to be adequate and sufficient if a well-proportioned dynamic Masculine is to emerge; otherwise the result is a distortion of the differentiation process with its concomitant effects of onesidedness. This dissonance in the Afrikaner volk was outlined in the unfolding of historical events and the response patterns of the Afrikaner, and will subsequently be discussed.

Historical events such as The Great Trek (1838), the Transvaal War of Independence (1880-1881), the Battle of Blood River, and especially the second Anglo-Boer War (1899-1902) are often regarded as some of the major historical events which played a role in the formation of Afrikaners' cultural identity (Laubscher 2005:309). Within the premises of Hill's (1992) model, it can be speculated that the dynamic Masculine was evident in the formation of the Afrikaner cultural identity during these events and whilst the Afrikaners were asserting themselves as a volk. The word volk is used in the sense of 'our own people' or, in the fullness of time, 'we the Afrikaners' (Le May 1995:55).

Leach (1989:17) claims that the Great Trek is a focal point in Afrikaner history, an event which gave the volk its first sense of direction. Commonly known as the Voortrekkers (Cock 1991:30), these pioneers were exposed to primitive living conditions and several warlike situations. Under the auspices of the phallic, dynamic Masculine (Hill 1992:12), the Voortrekkers differentiated themselves as a separate entity by showing the drive and courage to explore and conquer new frontiers and unknown territories and to harness new land and nature. They were trying to find their own authentic collective identity through an expression of courage and will. As evidenced by the dynamic Masculine (Hill 1992:9), it involved a major period of exploration, discovery and movement into a new world.

Simultaneously, an idealistic paradigm was set out by the Dutch Reformed Church, informing the Afrikaner people that they had a Christian, civilising mission to perform in South Africa (Leach 1989:29). It was stated that Afrikaners were a distinct people, occupying a distinct fatherland, and endowed by God with a distinct destiny (Steyn 2001:29; Thompson 1990:45). This sense of having a special destiny as a chosen people in the land they were opening up for White settlement was confirmed when the Voortrekkers, in the face of seemingly impossible odds, won the Battle of Blood River after making a covenant with God. In times to come this event would play an important role in uniting Afrikaners spiritually (Steyn 2001:33) and it remained a crucial component of Afrikaner identity (Steyn 2001).

The Voortrekkers had originally consisted of several Afrikaner groups who settled in different geographical areas (Leach 1989:29) in Southern Africa south of the Limpopo River. In due time, they declared themselves independent 
Boere republics. The British, under the military leadership of Lord Carnarvon, aimed at bringing about a united South Africa through federation under the British flag. This led to the annexation of the Transvaal, the subsequent First Boer War (1880-1881), and the Anglo-Boer War (1899-1902) (Van Jaarsveld 1978:30-31, 41). During the wars, the dynamic Masculine was clearly evident in the Boere's fierce defence of their newly found independence and their drive to assert themselves as a volk. Many Afrikaners still regard the Anglo-Boer War as the 'dark night' of 1899-1902. The Boere asserted themselves with desperation (violent dynamic Masculine protest) against the renewed onslaught of the 'Terrible devouring Mother' and suffered the loss of 26000 women and children in the concentration camps that were set up across South Africa during this time. This war, when their nation was almost stamped out, became pivotal for Afrikaner cultural identity (Faber 1990:59).

These threats of extinction and inadequate experiences of the static Feminine reinforced the complex around the image of the 'Terrible Devouring/Persecutory Mother' in the Afrikaner volk, leaving the dynamic Masculine fragile, violent, unstable, persecuting, overemphasised, and fixated as it endeavoured to establish its potency (against the onslaught and threat of being swallowed by the Feminine). This fixation could possibly have led to the formation of the so-called persecution complex (Hugo 1988:575; Van Jaarsveld 1978:39). These events also foretold the grim reality that these archaic anxieties would be projected onto anyone or any people that could be experienced as 'devouring, dangerous or overwhelming'. According to Weisstub and Galili-Weisstub (2004:147) the traumatogenic agent is often a culturally identified enemy. The defences evoked are part of a cultural complex, experienced not only by the victims themselves, but also by others belonging to the attacked group. Weisstub and Galili-Weisstub (2004) identified three components to this particular type of complex which is activated when the group spirit is threatened, namely:

1. traumatic injury to a vulnerable group of people or place of value that carries or stands for the group spirit

2. fear of annihilation of the group spirit by foreign others

3. emergence of avenging protector or persecutor defences of the group spirit. (p. 153)

The dynamic Masculine became distorted and one-sided as it constantly had to prove and protect its own potency in the face of threats to its survival. It can therefore be argued that the static Feminine or dynamic Masculine polarity with its issues of containment, safety, and security on the one hand and those of separation and differentiation on the other hand, as well as a struggle between impotence and potency, was subsequently not negotiated successfully in the Afrikaner volk. In the process of founding an independent Afrikaner identity through separation (healthy dynamic Masculine), survival and separateness therefore became synonymous with separation, constellating a further complex of separateness (Faber 1990:59) on the static Masculine or dynamic Feminine polarity.
According to Hill (1992:23), the countervailing influence of the dynamic Masculine is the activation of the static Masculine. In order to give structure and form to the Afrikaner's specific heroic strivings for survival and separateness, and also as a strategy against the perceived threats, a period of integration was therefore begun under the auspices of the static Masculine which was characterised by a pull towards social organisation (Hill 1992:28).

\section{The static Masculine in Afrikaner cultural identity: Shared expectations, standards, social hierarchies and order through rules of law}

The Boere eventually lost the Anglo-Boer War and signed over their independence and sovereignty to the British. With earlier collective wounds reinforced and no psychological space for healing and integration, the stage was set for Afrikaners (in their re-recovery of themselves as a volk) to rally around these archaic anxieties and distortions in the form of the static Masculine. The arguably disproportionate static Feminine and dynamic Masculine would find echoes in the emergence of a particularly strong static Masculine (which would quickly progress into a negative Masculine consciousness), and the subsequent constellation of a strong patrivalent cultural pattern (Hill 1992:163-167). This was clearly evident in the historical events involving the Afrikaner after the Anglo-Boer War. The predisposition that Afrikaners could only realise, maintain, and protect their cultural identity through separation and isolation, became overly entrenched in the static Masculine ideology of social structure and order that, in turn, was central to Afrikaner cultural identity.

After the British 'scorched earth' policy during the second Anglo-Boer War, the Afrikaners were a defeated, uprooted, poorly educated, and impoverished volk (Alberts 2005:33-39; Jacobs 2005:24; Van Jaarsveld 1978:26; Wessels 2005:13-16), and their language, culture, and sense of belonging were fractured (Giliomee 1981:78; Leach 1989:28-29). In a society in which urban and capitalist values predominated, the Afrikaners were not only from a rural origin and the poorest White group, but were also perceived as culturally backward and lacking in sophistication (Giliomee 1979:111; Giliomee 1981:78). The Afrikaner intelligentsia feared that the general state of the Afrikaner was threatening the volk's survival (Giliomee \& Mbenga 2007:290). Their survival necessitated movement into unknown territory, embodied in rapid urbanisation and the accumulation of capital. But ultimately the dislocation of rapid urbanisation at a comparatively late stage, as well as the Afrikaner's poverty, servitude, and desperate search for work in urban areas, fed a sense of dependency, inferiority, and a lack of selfconfidence (Giliomee \& Mbenga 2007:279; Giliomee 1979:111; Giliomee 2003:460; Leach 1989:30). This deepened their sense of insecurity, and subsequently, led to the reinforcement of deep psycho-social fears and resentments in the Afrikaner (Giliomee 1979:111; Leach 1989:30). In Jungian terms this severe lack of self-confidence often creates the conditions for an enantiodromia, resulting in excessive nationalism and dangerous ego inflation (Ramos 2004:108). 
It was at this juncture in the history of the Afrikaner that the emergence of some of the characteristics of the patrivalent cultural pattern became evident. The National Party, which was an Afrikaner ethnic national movement, was committed to helping poor Afrikaners. The Volkskongres of the Dutch Reformed Church stressed that attempts to rehabilitate poor Afrikaners had to be seen as 'fair and healthy' towards other population groups in South Africa (Giliomee \& Mbenga 2007:282). After various parliamentary debates, it was decided that the focus on Afrikaner poverty was fair, just, and Christian, as it had sufficient elements of 'justice and fair play and fruitfulness for the future' (Giliomee \& Mbenga 2007:288). According to Hill (1992:28), the rules of laws in patrivalent cultures are continually developed out of a consensus about what works best and what is fair.

The Afrikaner middle-class was most attracted to a strategy of ethnic mobilisation in order to overcome the deep feelings of insecurity and social inferiority (Leach 1989:30-31). In static Masculine terms, the ethnic mobilisation of the volk necessitated the creation of a much stronger social order and structure within which the core of the Afrikaner's cultural identity could prosper. This was achieved by the reinforcement of shared cultural symbols, a common sense of history and heritage, a distinct language, and the creation of an overriding religious structure (Heaven et al. 2000:71; Giliomee \& Mbenga 2007:290; Thompson 1990:160).

Stories of the Trek, Blood River and the suffering of women and children during the Anglo-Boer War were resurrected in the Afrikaners' consciousness in order to create a common sense of history and heritage (Malan 1964:131-132). Culture, language and religion also proved extremely useful for Afrikaner mobilisation, and for the development and reinforcement of group consciousness and collectivism. Braaivleis (barbeque), a re-enactment of how the Voortrekkers cooked their meals in the veld, was made fashionable amongst city people (Giliomee \& Mbenga 2007:290), and certain politicians argued openly for national symbols such as a national anthem and a South African flag (Malan 1964:154-185; Heaven et al. 2000:71). The song, Die Stem van Suid-Afrika (The Call of South Africa), became the Afrikaners' national anthem for all practical purposes, whilst specific folk songs became an integral part of popular culture (Giliomee \& Mbenga 2007:290). Afrikaans replaced Dutch as an official language, together with English (Thompson 1990:160). Afrikaans was linked with Afrikaner nationalism, and had a profound effect on the social identity of Afrikaners (Heaven et al. 2000:70; Moodie 1975:47-48).

Cultural symbols inculcated the belief that Afrikaners were 'God's people', and helped to shape their common sense of purpose and view of themselves as a 'spiritual entity' in South Africa. A particular Kuyperian Calvinism had been theorised as an overriding religious structure through which the meaning of historical events, and the dynamics of Afrikaner group identity, was filtered (Landman 1994:15; Laubscher 2005:309). The Calvinist ethic of pre-determinism and the belief in a 'fair and just world', became the underpinnings of the White Afrikaans-speaking, patriarchal community (Landman 1996:7; Moodie 1975:ix; Stones, Heaven \& Bester 1993:116).

Through the establishment of this clearly-defined social order, acquired by consensus and reinforced by civil theology, as well as the creation of standards relating to group membership, the Afrikaner cultural identity, or Afrikanerdom, was now deeply embedded in the patrivalent cultural pattern. The social order was further endorsed by official policies and rules of law when the National Party came into power in 1948. Through legislation, the National Party played a major role in the fulfilment of the Afrikaner's economic and political autonomy as well as cultural goals, and subsequently in the eventual triumph of Afrikanerdom (Giliomee 1979:111; Moodie 1975:115; O'Meara 1983:255). The party also introduced its Apartheid policy, designed to protect advantaged Whites, particularly White Afrikanerdom, through the rigorous separation of racial groups (Lambley 1980:3; Steyn 2001:xxiii-xxiv).

The aim was for Afrikaners to remain a separate race whilst enjoying their positions of privilege (Giliomee 1981:89-90). By means of the apartheid policy, the Afrikaner's social order was taking the form of an ideological final solution for survival (Faber 1990:58). Therefore, Afrikaners rallied around their archaic anxieties and distortions in the form of the static Masculine-driven order of Afrikaner nationalism, and its inhuman destructive apartheid policies. These policies, fuelled by fear, were intended to ensure survival by warding off the 'Devouring Other' in the form of complete separateness [apartheid]. Fixating on, and identifying with the static Masculine polarity, the cultural ego was now caught in its complex of separateness.

What was specifically pronounced in the Afrikaner patrivalent cultural pattern (Hill 1992:164) was the maintenance and preservation of this unique identity. The Afrikaner child was taught the Afrikaner system and its values, as well as the standards and expectations for individual achievement within Afrikanerdom, and was exposed to a reality which supported these values (Hill 1992:95; Lambley 1980:201; Thompson 1990:198). The Afrikaners' language was unique to Southern Africa, and from cradle to grave Afrikaners experienced little that was not the Nationalist world perspective: at home, in Afrikaans-language schools and universities, in Dutch Reformed Churches, in social groups, on radio and television, and in books and newspapers. The government enforced a remarkably strict censorship on every item coming into South Africa, whatever the medium (Lambley 1980:199, 252).

By setting the standards for qualifying for a particular status within Afrikanerdom, Afrikaners were submitted to the collective will of the societal conventions of the static Masculine with its underlying archetype, the Great Father (God, volk, and fatherland). The social order was based on separateness, to keep survival and cultural identity intact, based on an Afrikaner nationalism deeply embedded in 
Kuyperian Calvinism, consisting of strong expectations regarding adherence to group membership. The impact of the Afrikaner cultural identity on the mentality of Afrikaners was profound. The strongest guarantee for survival in the Afrikaner was the static Masculine in its drive towards adherence to the laws of the patriarchal Father-God and unquestioning obedience to the authority of his church-state apostles and captains (Faber 1990:60).

The excesses and dominance of the static Masculine, with its negative implications of rigidity, dehumanising righteousness, complacency and eventually lifelessness (as it suppresses spontaneity and creativity, and blocks all means of renewal) can clearly be seen in the violent political reactions from opponents of the apartheid system. South Africa had the undesirable distinction in the contemporary world of being the White supremacist Apartheid society, legally structured along the axis of race, with a legacy of deeply troubled intercultural and interracial relations (Steyn 2001:xxi). Opposition movements such as the African National Congress (ANC) and the South African Communist Party (SACP) were banned, because they were labelled as a threat to the safety and survival of the Afrikaner and their cultural heritage. It was only during the 1970s that the ANC began applying the effective strategy of popular mobilisation and mass protests against apartheid (Giliomee \& Mbenga 2007:307). The reaction to this violent political resistance, as well as to what was seen as domestic terrorism by the Apartheid Government, took the form of military protection against a subordinate Black population that was poor and without rights (Cock 1991:33; Giliomee \& Mbenga 2007:360-362; Van Jaarsveld 1978:251). The Afrikaner nation reverted to the negative dynamic Masculine (violence and destruction) in the suppression of these threats. Afrikaners often justified their actions in terms of patriotism ('I did it for volk and vaderland') (Laurence 1990:42).

According to Singer and Kimbles (2004:7) cultural complexes structure emotional experience and collect experiences that confirm their historical point of view. The inner sociology of the cultural complexes can seize the imagination, the behaviour and the emotions of the collective psyche and unleash tremendously irrational forces in the name of their 'logic'. They can provide for those caught in their potent web of stories and emotions a simplistic certainty about the group's place in the world in the face of otherwise conflicting and ambiguous uncertainties. Zoja (2004:87) states that collective trauma that befalls people is remembered for generations and become the core around which a cultural complex forms. Every time the complex is activated, repetitive memory and emotion appear and evoke the primal trauma. Therefore, trauma, memory and emotions recur.

According to Hill (1992:165), the patrivalent cultural pattern is characterised by constant tension between the tendency of the establishment viewpoint to become rigidified and complacently righteous (negative static Masculine) and the shock of innovation (dynamic Feminine). The tension characteristic of an extreme polarisation of opposites - in this case, between the static Masculine or dynamic Feminine polarity, cannot endure indefinitely. The extreme one-sidedness of the static Masculine inevitably leads to a forceful constellation of the dynamic Feminine in its urge for change and renewal.

\section{The dynamic Feminine in the Afrikaner cultural identity: Perceived chaos, sacrifice and possible renewal}

Since the static Masculine underlies the patrivalent cultural pattern, the dynamic Feminine is in the Shadow (Hill 1992:165). The Shadow refers to parts that would ordinarily belong to the ego, but that have been suppressed because of cognitive or emotional dissonance. These parts have therefore not been integrated into the ego (Stein 2010:106). According to Hill (1992:165), the dynamic Feminine tends to be carried by certain individuals or groups within that culture, such as artists and social revolutionaries, who give it form and expression. These new forms and ideas often first find their way into the subcultures of the young, where they are passionately taken up and promulgated.

The presence of the dynamic Feminine in the Shadow of the Afrikaner cultural identity became evident when certain South African writers, artists, actors and comedians questioned, attacked, or made fun of the Afrikaner cultural identity and the prevailing political system. In the early 1980s especially, it became apparent that the younger Afrikaner generation was beginning to challenge their traditional Afrikaner identity and culture through two new popular music and cultural movements, the Musiek- en Liriekbeweging and the Alternatiewe Afrikaanse Beweging or Voëlvry-beweging (Laubscher 2005:313). The constellation of the dynamic Feminine in the Shadow was particularly evident in the words of many of these songs, where the image and identity of the Afrikaner, crafted and created by an older generation, was soundly repudiated (Goodwin \& Schiff 1995:182). The Afrikaner youth's dissatisfaction with the status quo was made known in their desire to shock, to disturb the complacency of the establishment and to awaken it to a new consciousness for the collective. The dynamic Feminine (as it compensates the static Masculine) awakened a crisis of meaning and authenticity, and took the form of a disintegration of orientation and values.

Immense pressure from international and domestic sources during the late eighties caused the political emphasis in South Africa to change to reconciliation and domestic dialogue (Steyn 2001:xxi). The National Party's rule of forty years started to crumble, whilst the Dutch Reformed Church, that had justified apartheid on the basis of God's creation of distinct peoples, was expelled by the World Alliance of Reformed Churches in 1982. The ANC and other liberation movements were unbanned in the early 1990s (Giliomee \& Mbenga 2007:396).

It was clear that the dynamic Feminine was demanding the sacrifice of existing values in order to reach new levels of integration (Hill 1992:26). The scaffolding of the policies 
and laws around the Afrikaners' identity, which had preserved the uniqueness of the Afrikaners, were removed, making it less easy for them to maintain their distinctiveness (Korf \& Malan 2002:151). This resulted in a fragmented and ideologically contradicted construction of Whiteness within the country, and a lack of consensus about whom and what the Afrikaner was (Louw-Potgieter 1988:130; Steyn 2001:155). Changes, losses, and collective guilt led to a process where Afrikaners had to renegotiate, willingly or unwillinglytheir identity, 'selecting, editing, and borrowing from the cultural resources available to them to reinterpret old selves in the light of new knowledge and possibilities' (Steyn 2001:xxi-xxii). Research during this time showed the existence of a multitude of different 'Afrikaner identities', actively constructed by various groups of Afrikaans speakers (Steyn 2001:xxiii).

Subsequently, in April 1994, with the first democratic elections, South Africa captured the world's imagination as a country that had turned its history around (Steyn 2001:xxi). In the so-called 'new South Africa', a new national flag and anthem successfully blended diverse historic symbols and songs. A society whose citizens had struggled from the start to live with one another were joining forces to attempt, against considerable odds, to forge a new nation from the bottom up (Giliomee \& Mbenga 2007:433). Research conducted in the new democratic South Africa during the early 21st century indicated that the majority of all the various cultural groups in South Africa were proud to be identified as South Africans, and considered being a South African an important part of their social identity (Giliomee \& Mbenga 2007:433). However, within the South African context it is not yet clear what new cultural identity or identities the Afrikaners have or will have. According to Hill (1992:172), cultures move through this process towards bringing the differences between peoples out of the Shadow into the light, with a gradually increasing emphasis on static Feminine inclusion of everyone.

\section{Conclusion}

It has been argued here, within the premises of Hill's (1992) model, that the Afrikaner cultural identity and concomitant complexes were forged from traumatic events in the static Feminine, constellating primal fears relating to survival and separation. This led to a 'flight into the Masculine' and the constellation of cultural complexes around the 'Terrible Devouring/Persecutory Mother', persecution, and separateness. Subsequently the Masculine was elevated in its dynamic, and, more especially, static forms, in order to differentiate the Afrikaners as a volk, and to ensure their future survival through the fierce protection of their separateness. It has been argued further that the change and transformation of Afrikaner cultural identity was inevitable under the auspices of the dynamic Feminine.

The excessive 'flight into the Masculine' points to the possibility that earlier traumatic wounding in the static Feminine and the subsequent traumas of massacres and wars have not been processed adequately, leaving the Afrikaners' collective identity insecure, non-trusting, fearful and vulnerable. If the effects of this early wounding are to be healed, the Afrikaner collective identity must become conscious of the possible existence of these complexes, and it also needs to become safe and secure enough to affirm its own authentic existence in a culturally diverse society. A new integration is furthermore predicated upon the successful withdrawal of projections and the successful integration of the Shadow (Faber 1990:60). This would entail a genuinely equal relationship with other South Africans, with its concomitant revision of Afrikaner identity that would include a more all-embracing, synthetic and global identity which functions in terms of relatedness instead of exclusive separateness and isolation (Faber 1990:60). Undoubtedly, many Afrikaners have taken this route after 1994, but it seems that many may still need to address these. As was stated by De Vries (1974:23), 'no man is an island' and whilst the greatest commandment is that we love God above all else, the second, like unto it, commands our concern for our fellow man. Perhaps the Afrikaners interpreted their responsibilities to their neighbour far too narrowly and limited their neighbourhood far too much.

Upon reflection on the proposed individuation process of the Afrikaner cultural identity, as based on the premises of Hill's model, several aspects of Jung's view on human functioning and human cultures became evident. Firstly, Jungian psychology embraces the universe in all it manifestations, including components such as history, art, myth, philosophy and spirituality, in its endeavour to understand human functioning (Jung 1977:5). Secondly, from Jung's perspective, culture is seen as being transmitted through the evolution of the human mind and spirit and its expression in stories and mythologies about how the world works and about the human or group's place in it (Ramsden 2010:5). Both these aspects were evident in the proposed individuation process of the Afrikaner cultural identity. Cultural symbols, music, historical events and religion played an integral role in the development of the Afrikaner cultural identity, whilst the Afrikaners' beliefs, thoughts and spirit were transmitted by means of stories and the education system, where Afrikaner children were taught its values.

Furthermore, in the Jungian paradigm all human cultures are seen as having their roots in and centred around a religious viewpoint, as was evident in the Great Father-God Calvinistic, patriarchal ethic of Afrikanerdom. Jung's assertion of the religious function in the human being is grounded in the drive towards wholeness and individuation (guided by the Self). Jung's perspective on the place of religion in culture seems to be quite similar to the Christian-Reformational perspective of Van der Walt (2003:94-96), who proposed a holistic model of culture, consisting of five layers. Religion and worldview are seen as the deeper, invisible core facets of culture and form the heart or soul of culture. According to Van der Walt (2003:97), real, deep change in any culture is 
stimulated from its core whilst the remainder of the culture also influences religion and worldview. Therefore, a change caused by the influence of the outer layers of a culture on the centre may result in a complete 'power shift' at the core, destroying or replacing the original religious commitment (Van der Walt 2003:97).

Every culture has its 'blind spots' (Van der Walt 2003:99) which can be harmful (Lewis 1995:20). These 'blind spots' mainly occur because the equality of the four basic relationships determining our place in creation is not acknowledged (Van der Walt 2003:99): our relationships with God or god, nature, our fellow human beings and ourselves. From a Christian perspective, it can be said that because of the sinfulness of mankind the Afrikaners may have had a split between their religious loyalty (their relationship with God), and their loyalty to their worldview (their relationship towards the world). This was evident in the Christiannational ideology behind apartheid, which caused a split between Christian belief and national patriotism, which, in its turn, probably left the Afrikaner with a 'divided soul' (Van der Walt 2003:97, 98).

Jung's views on individuation and human cultures as well as Van der Walt's (2003:94-97) perspectives on the place of religion in culture therefore led to the argument that the individuation of the Afrikaner and the evolution of the Afrikaner cultural identity will most probably include a renewal of some of its religious viewpoints, including its integration with a renewed worldview. Jung's theory emphasises the continuous drive of the psyche towards the development of consciousness and the integration of these structures in order to create wholeness (Stein 2010:171-197). Jung (1969:347) sees the essence of the Self as the inner image of God, the living Spirit, residing in the individual. God, the Divine Spirit, continually grows and even outgrows its earlier forms of expression. Therefore the Self is eternally renewed and pursues its goal in manifold and inconceivable ways throughout the history of mankind. The names and forms which men have given it, mean very little - 'they are the changing leaves and blossoms on the stem of the eternal tree' (Jung 1969:347).

\section{Acknowledgements Competing interests}

The authors declare that they have no financial or personal relationship(s) which may have inappropriately influenced them in writing this article.

\section{Authors' contribution}

M.K. (University of the Free State) was mainly responsible for the section on Afrikaner history. L.G. (University of the Free State) was mainly responsible for the section on Jungian psychology. Both authors were involved in the conceptualisation of the study, as well as in the application of the Post-Jungian model on the Afrikaner history.

\section{References}

Alberts, P., 2005, 'Dokumentering van die brutaliteit van oorlog', in P. Alberts (red.), Die smarte van die oorlog, pp. 33-40, Kraal Uitgewers, Brandfort.

Cock, J., 1991, Colonels \& cadres: War \& gender in South Africa, Oxford University Press, Cape Town.

De Vries, G., 1974, 'A plea for social responsibility', The Reformed Journal, January, 22-25.

Faber, P.A., 1990, 'Archetypal symbolism and the ideology of apartheid', in G. Saayman (ed.) Modern South Africa in search of a soul: Jungian perspectives on the wilderness within, pp. 47-64, Sigo Press, Boston.

Giliomee, H., 1979, 'The growth of Afrikaner identity', in H. Adam \& H. Giliomee (eds.), The rise and crisis of Afrikaner power, pp. 83-127, David Philip, Cape Town.

Giliomee, H., 1981, 'Die ontwikkeling van Afrikaner-identiteit', in H. Giliomee \& H. Adam (reds.), Afrikanermag: Opkoms en toekoms, pp. 77-109, SunMedia, Stellenbosch.

Giliomee, H., 2003, The Afrikaners - Biography of a people, Tafelberg, Cape Town.

Giliomee, H. \& Mbenga, B., 2007, The new history of South Africa, Tafelberg, Cape Town.

Goodwin, J. \& Schiff, B., 1995, Heart of whiteness: Afrikaners face Black rule in the new South Africa, Scribner, New York.

Heaven, P.C.L., Stones, C., Simbayi, L. \& Le Roux, A., 2000, 'Human values and social identities among samples of White and Black South Africans', Internationa Journal of Psychology 35(1), 67-72.

Hill, G.S., 1992, Masculine and feminine: the natural flow of opposites in the psyche, Shambhala, Boston \& London.

Hugo, P., 1988, 'Towards darkness and death: Racial demonology in South Africa', The Journal of Modern African Studies 26(4), 567-590.

Jacobs, F., 2005, "n Vallende traan', in P. Alberts (red.), Die smarte van die oorlog, pp. 19-31, Kraal Uitgewers, Brandfort.

Jung, C.G., 1966, The collected works of C.G. Jung - The practice of psychotherapy volume sixteen, transl. R.F.C. Hull, 2nd edn., Routledge \& Kegan Paul, London.

Jung, C.G., 1969, The collected works of C.G. Jung - The practice of psychotherapy volume eleven, transl. R.F.C. Hull, 2nd edn., Routledge \& Kegan Paul, London.

Jung, C.G., 1977, The collected works of C.G. Jung - The practice of psychotherapy volume eighteen, transl. R.F.C. Hull, 2 nd edn., Routledge \& Kegan Paul, London.

Korf, L. \& Malan, J., 2002, 'Threat to ethnic identity: The experience of White Afrikaans-speaking participants in post-apartheid South Africa', Journal of Social Psychology 142(2), 149-169.

Lambley, P., 1980, The psychology of apartheid, University of Georgia Press, Athens, Georgia.

Landman, C., 1994, The piety of Afrikaans women: Diaries of guilt, University of South Africa, Pretoria.

Landman, C., 1996, 'Christian women in South African historiography - an overview', in C. Landman (ed.), Digging up our foremothers: Stories of women in Africa, pp. 3-26, University of South Africa, Pretoria.

Laubscher, L., 2005, 'Afrikaner identity and the music of Johannes Kerkorrel', South African Journal of Psychology 35(2), 308-330.

Laurence, P., 1990, Death squads: Apartheid's secret weapon, Penguin, Johannesburg.

Leach, G., 1989, The Afrikaners: Their last great trek, Johannesburg, Southern Book Publishers.

Le May, G.H.L., 1995, The Afrikaners: An historical interpretation, Blackwell Publishers, Cambridge, United Kingdom.

Lewis, C.S., 1995, Christian Reflections, William B. Eerdmans, Cambridge, United Kingdom.

Louw-Potgieter, J., 1988, Afrikaner dissidents: A social psychological study of identity and dissent, Multilingual Matters, Clevedon.

Malan, D.F., 1964, Glo in u volk, Tafelberg, Kaapstad.

Mattoon, M.A., 1981, Jungian psychology in perspective, Free Press/Collier Macmillan, New York \& London.

Moodie, T.D., 1975, The rise of Afrikanerdom, University of California Press, Berkeley.

Neumann, E., 1971, Amor and Psyche, 1st edn. 1956, Princeton University Press, Princeton.

O'Meara, D., 1983, Volkskapitalisme: Class, capital and ideology in the development of Afrikaner nationalism, 1934-1948, Cambridge University Press, Cambridge.

Ramos, D.G., 2004, 'Corruption', in T. Singer \& S.L. Kimbles (eds.), The cultural complex - Contemporary Jungian perspectives on psyche and society, pp. 102-123, Routledge, East Sussex.

Ramsden, R., 2010, 'Historical backdrop to the Mother Archetype', paper presented at Alchemy as mirror of the human psyche: As above, so below Symposium, Cape Town, 24-28 September.

Samuels, A., 1985, Jung and the post-Jungians, Routledge \& Kegan Paul, London.

Singer, T. \& Kimbles, S.L., 2004, 'Introduction', in T. Singer \& S.L. Kimbles (eds.), The cultural complex - Contemporary Jungian perspectives on psyche and society, pp. $1-9$, Routledge, East Sussex. 
Stein, M., 2010, Jung's map of the soul - An introduction, Open Court, United States.

Steyn, M., 2001, 'Whiteness just isn't what it used to be': White identity in a changing South Africa, State University of New York Press, Albany, New York.

Stones, C.R., Heaven, P.C.L. \& Bester, C.L., 1993, 'The perception of political events in South Africa and personality correlates', Journal of Social Psychology 133(1), 15-118.

Sullivan, B.S., 1989, Psychotherapy grounded in the feminine principle, Chiron Publications, Wilmette.

Thompson, L., 1990, A history of South Africa, Yale University Press, New Haven.

Ulanov, A.B., 1971, The feminine in Jungian psychology and in Christian theology, Northwestern University Press, Evanston.

Van der Walt, B.J., 2003, Understanding and rebuilding Africa, Institute fo Contemporary Christianity in Africa, Potchefstroom.
Van Jaarsveld, F.A., 1978, Omsingelde Afrikanerdom, HAUM, Pretoria.

Weisstub, E. \& Galili-Weisstub, E., 2004, 'Collective trauma and cultural complexes', in T. Singer \& S.L. Kimbles (eds.), The cultural complex - Contemporary Jungian perspectives on psyche and society, pp. 147-170, Routledge, East Sussex.

Wessels, E., 2005, " $n$ Engel van liefde', in P. Alberts (red.), Die smarte van die oorlog, pp. 13-25, Kraal Uitgewers, Brandfort.

Whitmont, E.C., 1980, 'Reassessing femininity and masculinity: Critique of some traditional assumptions', Quadrant 13(2), 109-122.

Whitmont, E.C., 1983, The return of the goddess: Femininity, aggression and the modern Grail quest, Routledge \& Kegan Paul, London.

Zoja, L. 2004, 'Trauma and Abuse', in T. Singer \& S.L. Kimbles (eds.), The Cultural Complex - Contemporary Jungian Perspectives on Psyche and Society, pp. 78-89, Routledge, East Sussex. 